\title{
OF EARRINGS, SWALLOWS AND THERAN LADIES
}

Iris Tzachili

It seems that religious concepts in the Late Bronze Age settlement at Thera are essentially Minoan. Almost every phenomenon of Minoan religious life is present at Thera; moreover religious iconography is thought to be in a high degree dependent, or at least strongly influenced by Minoan themes (Sapouna-Sakellaraki 1976: 487-509; Cameron 1978: 580-592). The subject has in the last years been linked with an attempt to investigate the political schemes in the Aegean; that is whether Thera was, or was not, a Minoan colony and which was the role of religion in this political dependence (Marinatos 1984a: 176).

Yet one becomes easily conscious of some diverging details, either in the form of absences of well known Minoan themes, or of some particular features occurring almost exclusively at Thera. Usually these peculiarities are assigned to the older Cycladic tradition, (Barber 1978: 378-9; Thorpe-Scholes 1978: 444; Höckmann 1978: 615); or to Mycenaean influences (Doumas 1983: 132). The aim of this paper is to deal with two of them, not so arbitrarily chosen as it may seem at first sight; the earrings and the swallows.

The great majority of the Theran ladies depicted in the wall paintings are adorned with earrings. The priestess from the West House wears big, wheel-like ones (P1. 7), and the two female figures from the House of the Ladies wear earrings of the common crescent form (Pls. 8-9) as do the women who are depicted in the Crocusgatherers fresco in the house known as Xeste 3 . The earrings of one of the crocus gatherers (Pl. 10) are of exactly the same form as the golden ones found in Mycenae in Shaft Grave III (Sapouna-Sakellaraki 1976: 509), and thought to be Cretan work of Late Minoan Ia. Earrings are also worn by young boys, namely, one of the young boxers (Thera IV pl. E) and one of the recently found male figures in the Xeste 3.

This fact is hardly remarkable by itself; what is more natural for the glamorous Theran ladies than to be adorned with earrings along with necklaces, bracelets, diadems and so on? Earrings, furthermore are found in graves in Crete and the mainland, though not so numerous as the necklaces (Hood 1978: 194-207). It assumes significance only by 
comparison; in the whole Aegean iconography (Knossos, Mycenae, Pylos, Tiryns, Thebes) none of the female personnages wear earrings. They wear rich gowns, rich jewellery but no earrings (Tzachili 1985: 395).

Even after this observation the Theran earrings would not appear to be more than an additional refinement. But this does not seem so. There are indications that suggest that earrings are invested with a derived, secondary meaning, that they might be functioning as signs. This is denoted by the other puzzling representations of earrings in Theran iconography. We see them decorating vases around the handles in the form of rings as if handles were ears (Pl. 11). Not in any kind of vases. Only in nippled-ewers and sometimes flower-pots. The nippled-ewer, considered as a typical cycladic vessel, is characterized by two, non utilitarian features: the imitation of female breasts and the bird-like spout. The combination of these and the large "fertile" belly lead to ideas or images related to birds, women and fertility. Consequently this vase is often considered as a ritual one even though there are no archaeological data to confirm this assumption (Marinatos 1984a 177). Besides, the most important point is perhaps that the nippled-ewer is so far in Thera the only type of vase represented on another vase. Ewers, besides, are represented on a skyphos from Phaistos: one of the rare representations of a vase on another vase outside Akrotiri (Stümer 1985: 127, fig. 12). When a nippled-ewer is represented on a vase, two of its elements are emphasized, the nipples and the earrings, which are excessively big as if the artist wanted to make sure that people's attention would instantly be drawn on them. In one case the representation of a nippled-ewer on a large pithoid amphora is characterized by huge wheel-like earrings, the same as those worn by the priestess in the West-House.

This type of vase is frequently decorated with swallows, the other subject we are proposing to examine in this paper. Swallows are depicted frequently on Theran frescoes and vases, more frequently than in any other part of the Aegean (Marinatos 1969: 68), a curious phenomenon in the light of the fact that swallows do not stay to make nests in Thera, they just migrate through (Doumas 1983: 81). They are the main theme in the spring fresco (Marinatos IV, pl. A, B, C) a wall painting whose religious character has been doubted by none (Doumas 1983: 76) (P1. 12). Swallows are also depicted in two fresco fragments; one from the Xesté 3 which represents a swallow near a crocus cluster and another belonging to the Monkeys fresco (Marinatos, III pl. B a). We find them on a kymbe, on strainers and often on ewers. A nippled 
ewer with a swallow which was found in Mycenae comes probably from Thera (Marinatos 1969: 68). In 1984 beneath the ground floor of the West House several nippled-ewers were found all of them decorated with swallows. They were deposited in shallow pits whose function appears quite enigmatic.

Swallows are always rendered in the same conventional manner, black-and-white and with the bifurcated tail. Very often they are associated with crocuses and lilies, flowers well known for their symbolic dimension (Chirassi 1968: 126-134) and, being bulb plants, often brought in connexion with the cycle of regeneration (Ibid: 128129).

Finally there is one document of crucial importance since it permits a glimpse in the subtle play of the successive subtitutions. A bird, possibly a swallow, is depicted wearing earrings identical to those of the West House priestess (Pl. 13). Is the swallow standing for a girl? Is a definite female character visually symbolized by the swallow and emphasized by the earrings? As we shall see later, swallows as well as earrings point to a common path, youth and its ambiguities.

What kind of approach or interpretation may enable us to comprehend this sequence of related subjects? We may, of course, easily enough classify them in the current conceptual frames of the Minoan religion such as the cycle of life and death or the epiphany of a goddess in the form of a bird. These concepts were elaborated mostly by Evans, Persson and Nilsson. In their syntheses they tried to build a general and coherent system often on the base of similitudes with classical Greek religion. Therefore, we are equipped with interpretative concepts created for the needs of a descriptive synthesis. If we use these as a frame into which every single detail must find a way to fall, even those which tend to differentiate the religious elements in time, space and meaning, this mental procedure which seeks to explain the diverging details with interpretative concepts, seems to me a useless and meaningless tautology which can't help us to define the differences or catch the nuances. As a possible method to enlarge the scope of potential analysis, apart from sorting out the material and establishing the associations or visual connotations, I tried to follow in the Homeric poems the semantic field of the Greek word whose referent is depicted.

Let's have a look again at the Crocus-gatherers fresco. One trait that gets confirmation as restauration and research advances is the fact that the female persons form groups according to their age, presumable role in the ritual or social position. This is suggested by 
various details in the appearance, which are symbolical. Pausanias describing a fresco in Delphi mentions the same detail on a fifth century wall-painting: "Andromache and Medesicaste wear hoods; but Polyxena has her hair braided after the manner of the maidens" (Pausanias, 10, 25, 10). The same custom seems to prevail here; all girls who take part in these scenes, often considered as an initiation ritual (Marinatos 1984b: 73-84), have their hair uncovered, or seen through a transparent veil, whereas the others, who seem older, have their hair well covered by what in Greek is called the kredemnon. These last figures form another group but they still belong to the same pictorial programme. The interesting fact is that all the younger girls who have their hair uncovered wear earrings whereas the elder ones do not. Earrings together with other external features seem to assign them to a social group,determined by age. This kind of female communities must have been an important factor of social integration. In the Iliad (III, 175) when Helen evokes the beloved people she left behind, she

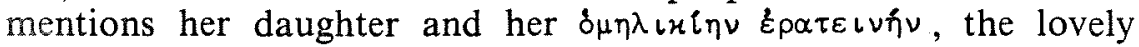
companions of her own age.

In the Homeric poems earrings are mentioned twice with the same

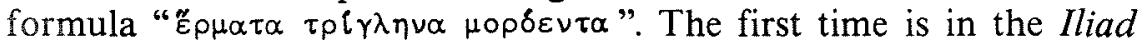
(XIV, 182). Hera prepares herself for the love-meeting with Zeus: "In her pierced ears she put earrings with three clustering drops; and abundant grace shone therefrom". She wants to convince him to stop helping the Troyans and to achieve this temporary neutrality she asks the assistance of Aphrodite and Hypnos. In doing so she will bring the wrath of Zeus upon herself and disaster on the Greeks. Her intervention by way of seduction threatens the natural and social order of the world expressed by the will of Zeus. The second time is in the Odyssey (XVIII, 297). One by one, Penelope's pretenders present to her their gifts. Eurydamas gives her a pair of earrings, the third in importance after a gown and a necklace. Here again we have an attempt of seduction which threatens directly Penelope's marriage. In both cases it is an attempt against the social order and in both cases it gets seriously repressed. In the Homeric context earrings seem to belong to the string of malefic jewels presented to young women by illintentioned persons in order to persuade them to forget their duty. They often possess magic powers. This dangerous ambiguity can hardly find a visual expression. We can only see the emphasis put on this detail; as it seems to be the case in the Theran wall-paintings.

Swallows are comparatively rare outside the Cyclades. At Akrotiri we have seen them on wall-paintings associated with lilies and 
crocuses as well as on vases. Here the interpretation seems plausible. Swallows throughout the whole Greek tradition (Classical, Byzantine and modern Greek) bring the message of spring, the renewal of hope, the resurrection of the earth and the whole nature (Marinatos 1968,6566). We find them in Classical vase-paintings, in Byzantine verses and in modern Greek folk-songs. Yet the contrary tradition exists as well. In the Odyssey, the swallow brings again a message, but it is one of disaster. Athena takes the aspect of a swallow during the killing of the suitors (XXII, 240) and the sound of Odysseus' bow is compared with the sound of a swallow (XXI, 411). The swallow is connected in mythology with Philomela, the unfortunate heroin who has been deprived of speech. The name of the swallow was used to express the incomprehensible speech, that is, the language of the barbarians. More significant for our scope is the use of the word swallow as a metaphor for the female sexual part (Aristophanes, Lysistrata, 770) and this in a context of a reversed order, where the revolt of the Athenian woman threatens their social role. Expression of youth and consequently immaturity, the swallow appears as the visual and mental metaphorical realization of youth, beneficent but socially uncontrollable and therefore potentially malefic.

At the end of this detour, in our attempt to understand the multiple levels of meaning, let us return to our iconographic details. They point to a female personality, young, versatile, ambiguous, dangerously attractive. It is impossible to say by which goddess or goddesses these elements are epitomised. Nevertheless she seems to be the counterpart of the fertility figures, desired, needed and controlled by agricultural societies. Here we are in the cultural sphere of a society whose wealth was acquired by trade, which can afford enough surplus time to permit its female members to elaborate on their appearances and send thus back to it the image of grace and wealth it obviously desires. 


\section{Summary}

The paper deals with some minor details occurring almost exclusively in the iconography of the prehistoric settlement of Akrotiri on Thera. These details, i.e. the persistent representation of ladies wearing earrings, the decoration of vases with painted earrings - and especially those called nippled-ewers which are frequently associated with fertility and ritual - and the persistent association between swallows, nippled-ewers, earrings and some flowers well known for their symbolic values (lilies, crocuses), tend to differentiate the religious concepts or, at least, denote the multiple levels and meanings of a religion thought to be Minoan.

\section{Résumé}

L'étude de quelques détails iconographiques des représentations à Akrotiri (Théra) peut conduire à des conclusions intéressantes quant à leurs particularités et surtout quant aux traits spécifiques de l'iconographie de Théra. Concernant leur interprétation, une possibilité autre que l'application des schémas bien connus de la déesse mère et de son conjoint, serait de s'appuyer aux textes homériques qui peuvent fournir des renseignements instructifs sur les multiples niveaux de signification et les ambiguités de sens de ces mêmes détails. 
Bibliography

BARBER, R.L.N.

1978 - Cyclades in the Middle Bronze Age, in Doumas (ed.), Thera and the Aegean World, 367-379, London.

CAMERON, M.A.S.

1978 - Theoretical Interrelations among Theran, Cretan and Mainland Frescoes, in Doumas (ed.), Thera and the Aegean World, 579. 592, London.

CHIRASSI, I.

1968 - Elementi di culture precereali nei miti e riti greci, Roma.

DOUMAS, C.

1983 - Thera, Pompei of the ancient Aegean, London.

HÖCKMANN, O.

1978 - Theran floral Style in relation to that of Crete, in Doumas (ed.), Thera and the Aegean World, 605-616, London.

HOOD, S.

1978 - The Arts in Prehistoric Greece, (Penguin Books).

MARINATOS, N.

1984a - Minoan Threskeiocracy on Thera, in Hägg, R. and Marinatos, N., (eds) The Minoan Thalassocracy, Myth and Reality, 167-178, Stockholm.

1984b - Art and Religion in Thera, Athens.

MARINATOS, $\mathrm{S}$.

1968 - Chelidonisma, Archaiologika Analekta Athinon, 65-69.

1968-1976 - Thera I-VII.

SAFFLUND, G.

1981 - Cretan and Theran Questions, in Hägg, R. and Marinatos, N. (eds), Sanctuaries and Cults in the Aegean Bronze Age, 189-208, Stockholm.

SAPOUNA-SAKELLARAKI, E.

1981 - Oi toichographies tes Theras se schesi me ten minoiken Kreten (Theran frescoes in relation with Minoan Crete), in Pepragmena tou $\triangle$ Diethnous Cretologikou Synedriou. (Acts of the IV International Congress for Crete),479-509 Heraklion.

STURMER, V.

1985 - Schnabelkannen: eine Studie zur darstellenden Kunst in der minoisch-mykenischen Kultur, in L'Iconographie Minoenne, Bullettin de Correspondance Hellénique, Supplement XI, 119134. 
THORPE-SCHOLES, $\mathrm{K}$.

1978 - Akrotiri, Genesis, Life and Death, in Doumas, C. (ed), Thera and the Aegean World, 437-447, London.

TZACHILI, I.

1985 - Ta skoularikia tes theas tes Kyprou kai oi mastoprochoi tes Theras (The Earrings of the Goddess of Cyprus and the Nippledewers of Thera), in Praktika tou B' Diethnous Kypriologikou Synedriou (Acts of the 2nd International Congress for Cyprus), Vol. I, 391-401, Nicosia. 